\title{
Yield and Chemical Composition of Raw Material from Meadow Arnica (Arnica chamissonis Less.) Depending on Soil Conditions and Nitrogen Fertilization
}

\author{
Katarzyna Olesińska (D), Danuta Sugier *(D) and Zdzisław Kaczmarski (D) \\ Department of Industrial and Medicinal Plants, University of Life Sciences in Lublin, 15 Akademicka Street, \\ 20-950 Lublin, Poland; katarzynaolesinska@tlen.pl (K.O.); zdzislaw.kaczmarski@up.lublin.pl (Z.K.) \\ * Correspondence: danuta.sugier@up.lublin.pl
}

Citation: Olesińska, K.; Sugier, D.; Kaczmarski, Z. Yield and Chemical Composition of Raw Material from Meadow Arnica (Arnica chamissonis Less.) Depending on Soil Conditions and Nitrogen Fertilization. Agriculture 2021, 11, 810. https:// doi.org/10.3390/agriculture11090810

Academic Editor: Sergio Esposito

Received: 26 July 2021

Accepted: 24 August 2021

Published: 26 August 2021

Publisher's Note: MDPI stays neutral with regard to jurisdictional claims in published maps and institutional affiliations.

Copyright: (c) 2021 by the authors. Licensee MDPI, Basel, Switzerland. This article is an open access article distributed under the terms and conditions of the Creative Commons Attribution (CC BY) license (https:/ / creativecommons.org/licenses/by/ $4.0 /)$.
Abstract: Considering the global tendency towards using valuable secondary metabolites of plant origin, there is a need to optimize the cultivation of herbal plants, e.g., the meadow arnica (A. chamissonis Less.). The inflorescences of this species (Arnicae anthodium) have a similar chemical composition and pharmacological activity to that in the mountain arnica (Arnica montana L.), and can be cultivated more easily than the mountain arnica. Therefore this study assesses soil and fertilization effects on the flower head yield and concentrations of active substances (sesquiterpene lactones, flavonoids, and essential oil) with great importance for application in the pharmaceutical and cosmetic industries. A field experiment was carried out during 2017-2019 on two types of soil (sandy and loamy soils) differing in the $\mathrm{pH}$ values, organic matter content, and the $\mathrm{P}, \mathrm{K}$, and $\mathrm{Mg}$ levels. Five levels of nitrogen fertilization were applied in both soil variants: $0,30,60,90$, and $120 \mathrm{~kg} \mathrm{~N} \cdot \mathrm{ha}^{-1}$. The study showed that both the soil type and the nitrogen fertilization had a positive impact on the raw material yield and the content and yield of the main active substances. The cultivation of arnica in the loamy soil was more favorable-it provided a higher flower head yield, higher levels of sesquiterpene lactones, flavonoids, and essential oils, and consequently, a higher yield of these metabolites. High flower head yields were achieved at doses of 60 and $90 \mathrm{~kg} \mathrm{~N} \cdot \mathrm{ha}^{-1}$. The content of sesquiterpene lactones and essential oils increased in the consecutive study years along with the increase in nitrogen doses. The highest content of flavonoids was detected in flower heads obtained from three-year-old plants fertilized with $60 \mathrm{~kg} \mathrm{~N} \cdot \mathrm{ha}^{-1}$. High yields of sesquiterpene lactones and essential oils were obtained at doses of $90-120 \mathrm{~kg} \mathrm{~N} \cdot \mathrm{ha}^{-1}$, whereas the fertilization with $60-90 \mathrm{~N} \cdot \mathrm{ha}^{-1}$ ensured a high yield of flavonoids. The yields of sesquiterpene lactones and essential oil did not depend on their concentration but correlated with the increase in the yield of flower heads of plants cultivated in both sandy and loamy soil variants. In turn, the yield of flavonoids was influenced by both their concentration and the flower head yield. The flower head yield, the content of sesquiterpene lactones, flavonoids, and essential oils, and the yields of metabolites presented in this study indicate favorable climatic conditions for the cultivation of A. chamissonis in Central and Eastern Poland. This proves that a wide range of pharmacologically active substances can be produced in this region of Europe.

Keywords: Arnica chamissonis Less.; nitrogen; soil type; sesquiterpene lactones; flavonoids; essential oil

\section{Introduction}

The meadow arnica (Arnica chamissonis Less.) is a perennial plant from the family Asteraceae with a native occurrence range covering the western regions of North America and British Columbia [1,2]. Its natural habitats are meadows, banks of streams, and alpine and subalpine forests with scattered tree stands [3,4]. With its large adaptive potential [5], the species can be successfully cultivated in other regions of the world with the temperate climate. To date, attempts have been made to cultivate meadow arnica in Europe, e.g., Poland, Serbia, and Lithuania [6-8]. Flower heads that can be used for pharmaceutical and 
cosmetic purposes are the main raw material of this species [7,9,10]. Additionally, scientific reports indicate the potential of practical applications of rhizomes (Arnicae rhizoma), leaves (Arnicae folium), flowering shoots (Arnicae herba), and seeds [11,12].

Among the 29 species representing the genus Arnica, the mountain arnica Arnica montana L., which is endangered with extinction and under strict protection in many European countries, has the greatest importance for the pharmaceutical industry [13-15]. The demand for arnica raw material has exerted pressure on naturally growing populations, i.e., by increased collection for medicinal purposes, which has led to a rapid decline in the abundance of this species in Europe [16-18]. The demand for Arnicae flos is not satisfied by either the few difficult and expensive commercial plantations or harvests from natural habitats, which are limited, due to conservation protection [19-22]. Hence, researchers looked for a species that was easier to grow and produced inflorescences with a similar chemical composition. Along with the increasing demand for arnica flower heads, new plantations were established in other regions of the country, thus increasing the acreage [23,24]. Given the growing demand for $A$. chamissonis raw material, new sites with favorable conditions for the cultivation of arnica, e.g., in eastern Poland, are being indicated.

The inflorescences of the meadow arnica (Arnicae anthodium) have a similar chemical composition and pharmacological activity to that in the mountain arnica (Arnica montana L.) [9,25-28]. There are literature reports on the antioxidant, antiseptic, and anti-inflammatory effects [9,14,29-32], and the potential use of arnica raw material in Alzheimer's disease and cancer treatment [33-35]. These properties are determined by the content of active substances in the meadow arnica inflorescences, e.g., sesquiterpene lactones, flavonoids, and essential oils $[6,36,37]$. Sesquiterpene lactones from Asteraceae plants may play a highly significant role in human health as part of a balanced diet and pharmaceutical agents, due to their potential in the treatment of cardiovascular and cancer diseases [38]. Additionally, they exert anti-inflammatory, analgesic, spasmolytic, biocidal, and antiviral effects [39-42]. Furthermore, the raw material contains flavonoids, phenolic acids, and essential oil, which complement the action of lactones, and are, thus, involved in the pharmacological effects $[9,10,27,37,43-50]$. Given the global tendency towards using valuable secondary metabolites of plant origin, there is a need to optimize the cultivation of such herbal plants as A. chamissonis.

Nitrogen is the most essential nutrient determining plant yields. It plays an important role in producing substantial amounts of plant biomass and is one of the basic elements in the plant structure. This element participates in producing primary and secondary metabolites and in the processes of photosynthesis and respiration. A positive effect of nitrogen was demonstrated, e.g., in experiments on summer savory [51], sage [52], lemon verbena [53], rosemary [54], and chamomile [55]. Król reported a beneficial effect of nitrogen fertilization on the weight of marigold seeds [56], and inflorescences [57,58] with a simultaneous increase in the content of essential oil and a decrease in the number of flavonoids in the raw material. In turn, other authors described reduced content of essential oil in raw material from lemon balm [59], clary sage [60], and Greek oregano [61,62] fertilized with nitrogen. Furthermore, different effects of nitrogen fertilization on the synthesis of flavonoids were demonstrated depending on the plant species: A positive impact on spearmint [63], no visible impact on yarrow [64], and a negative effect on artichoke [65], and Greek oregano [62]. As reported by Mijani et al. [66], plants fertilized with nitrogen at a rate of $75 \mathrm{~kg} \mathrm{~N} \cdot \mathrm{ha}^{-1}$ contained the largest amounts of essential oil, which declined after applying higher nitrogen rates. Similar responses were observed by Andrzejewska and Woropaj-Janczak [67], where an increase in the nitrogen rate from 60 to $90 \mathrm{~kg} \mathrm{~N} \cdot \mathrm{ha}^{-1}$ was accompanied by a decrease in the essential oil content in herbs, whereas the same level of these compounds was detected in the raw material. The role of nitrogen in the synthesis of sesquiterpene lactones has not been elucidated to date. Differences in plant response to nitrogen have been demonstrated in the Asteraceae family and the genus Chrysanthemum [68-70]. As shown by Wang and Tan [71] in their in vitro studies, not only the dose but also the nitrogen form and the ratio of both forms are important for 
the biosynthesis of lactones: Sources with a predominance of nitrates over the ammonium form are considered more favorable.

Generally, nitrogen application significantly increases crop growth parameters such as plant height, leaf area, and biomass. Research results reported in the literature do not clearly show only a positive response of herbal plants to nitrogen fertilization. The trade-off principle is observed, as in the case of the noticeably higher mass but lower content of flavonoids in Calendula officinalis L. [57,58]. Therefore, an increase in the nitrogen dose may increase biomass production and can reduce the concentration and yield of secondary metabolites. Hence, it is important to investigate the quantitative parameters of raw materials and the concentration and yield of secondary metabolites. These aspects are addressed in the present study of the A. chamissonis response to increasing nitrogen doses.

Currently, special attention is given in agriculture to the wide-scale adoptions of lowinput, soil-friendly, and resource-conserving agronomic practices, which are imperative for reducing carbon emissions and nitrogen losses from agricultural soil and reducing eutrophication. Sustainable agriculture strives for maintaining or even increasing productivity, quality, and economic viability, while leaving a minimal footprint on the environment $[72,73]$. Currently, in the field production of medicinal plants, it is necessary to reduce the doses of mineral fertilizers and pesticides [74]. To improve the use of $\mathrm{N}$ fertilizers and reduce environmental pollution in agriculture, it is essential to optimize the $\mathrm{N}$ fertilization rate, thereby meeting the actual requirements of plants and simultaneously reducing $\mathrm{N}$ fertilization substantially. Optimal doses of nitrogen application can be considered as a relevant method for modification of not only morphological traits but also the chemical composition in plants. They can also contribute to the increased production of secondary metabolites in controlled field conditions [10].

With the content of numerous pharmacologically active substances in its flower heads, A. chamissonis is a pharmaceutical substitute for the endangered A. montana $[3,9,29,36,75,76]$. Moreover, the meadow arnica can be cultivated more easily than the mountain arnica. Therefore, in the last decades, various agricultural factors have been studied in field conditions. Row spacing and the maturity of flower heads were found to have a significant impact on higher yields of flower heads and such secondary metabolites as sesquiterpene lactones, flavonoids, and essential oils [9,37]. Foliar boron fertilization is another factor affecting the essential oil content in Arnica chamissonis flower heads [76]; however, the variation in the content of basic metabolites in meadow arnica flower heads under nitrogen fertilization in different soil conditions has not been investigated. Therefore, the objective of this study was (i) to evaluate the impact of different soil types and nitrogen doses on the yield of flower heads of A. chamissonis cultivated in eastern Poland and (ii) to determine the concentration and yield of sesquiterpene lactones, flavonoids, and essential oils in the flower heads. These main groups of secondary metabolites characteristic for this herb species are important for using the raw material in the pharmaceutical and cosmetic industries.

The results of this study have extended the knowledge of the role of nitrogen in flower head yields in this species on the one hand. Moreover, they have shown the effect of nitrogen on the content and yield of sesquiterpene lactones, flavonoids, and essential oils in flower heads on the other hand. This highlights the role of nitrogen doses and the soil type as an environmental aspect [72]. The research results have supported the cultivation of $A$. chamissonis in Central Europe in sustainable environmental conditions allowing the optimal use of nitrogen to minimize its migration to the environment and prevent habitat eutrophication, which occurs when excessive doses of this macronutrient are applied.

\section{Materials and Methods}

\subsection{Plant Morphology}

The meadow arnica has a long (up to $30 \mathrm{~cm}$ ), thick $(1.5-2.5 \mathrm{~mm}$ ), unbranched, light brown, bare rhizome with numerous adventitious roots. In spring each year, it produces rosettes of lanceolate-ovoid leaves and $20-90 \mathrm{~cm}$ high inflorescence shoots branched in 
the upper part. The stem bears 5-10 pairs of $2-4 \mathrm{~cm}$ wide and $10-15 \mathrm{~cm}$ long leaves, decreasing in their sizes towards the apex. The tops of the branching shoots of the meadow arnica bear 3 to 15 flower heads. The light-yellow flowers are gathered in $4 \mathrm{~cm}$ diameter heads $[1,3,4]$. The flower heads are composed of numerous small disc florets surrounded by less numerous longer (usually $15-18 \mathrm{~mm}$ ) and shallowly dentate ray florets [1,77]. In Poland, the flowering of the species usually begins at the turn of May and June and lasts for approximately three weeks [7].

\subsection{Experimental Conditions}

The field experiment was carried out in two-, three-, and four-year-old arnica plantations in 2017-2019. The field experiment was established in the second ten days of April 2016. The field was deeply plowed after harvesting the forecrop (white mustard Sinapis alba L.) in autumn 2015. The next spring, a cultivator was used for soil tillage and leveling before setting up the experiment. Runners with 4 to 6 leaves and a well-developed $10 \mathrm{~cm}$ long underground rhizome were planted in the experimental plots. Immediately after transfer from the original plantation site (collection of the Department of Industrial and Medicinal Plants, University of Life Sciences in Lublin), the runners were planted into previously prepared furrows. They were planted at an $8-10 \mathrm{~cm}$ depth with $20 \mathrm{~cm}$ spacing and covered with soil. The $40 \mathrm{~cm}$ row spacing resulted in the density of 125,000 plants $\mathrm{ha}^{-1}$.

The first year of the experiment (2016) was regarded as a preliminary year (no nitrogen fertilization was used), due to the low yields of flower heads, as the plants produced runners and roots at the expense of the aboveground parts. Moreover, due to the poorly developed root system, there was a high probability in the first weeks after planting that the introduced nitrogen fertilizers would not be fully absorbed by the plants. The following years 2017-2019, were regarded as the production years and were presented in a factorial system.

The research was conducted in two locations in the eastern part of Poland, differing in soil conditions. The first experimental plot $\left(51^{\circ} 31^{\prime} 25^{\prime \prime} \mathrm{N} ; 22^{\circ} 45^{\prime} 04^{\prime \prime} \mathrm{E}\right)$ was located on podzolic soil—sandy soil (SS) characterized by moderate content of organic matter and phosphorus, low potassium content, very low magnesium levels, and very acidic $\mathrm{pH}$. The other part of the experiment was located on a plot $\left(51^{\circ} 29^{\prime} 28^{\prime \prime} \mathrm{N} ; 22^{\circ} 51^{\prime} 18^{\prime \prime} \mathrm{E}\right)$ with brown soil-loamy soil (LS) with high content of organic matter, very high content of phosphorus, moderate potassium and magnesium levels, and a neutral $\mathrm{pH}$ value (Table 1).

Table 1. Soil properties in the experimental plots $(0-30 \mathrm{~cm})$.

\begin{tabular}{ccccc}
\hline Content & Unit & Sandy Soil & Loamy Soil & Determination Method \\
\hline Sand & $\%$ & 66.2 & 21.5 & $*$ \\
Silt & $\%$ & 20.5 & 42.1 & \\
Loam & $\%$ & 13.3 & 36.4 & \\
\hline Organic matter & $\mathrm{g} \cdot \mathrm{kg}^{-1}$ & 16.7 & 20.8 & PB-34-Tiurin method \\
\hline Phosphorus & $\mathrm{mg} \cdot \mathrm{kg}^{-1}$ & 60.2 & 112.6 & PN-R-04023: 1996 \\
\hline Potassium & $\mathrm{mg} \cdot \mathrm{kg}^{-1}$ & 65.6 & 198.4 & PN-R-04022: 1996 + Az1: 2002 \\
\hline Magnesium & $\mathrm{mg} \cdot \mathrm{kg}^{-1}$ & 13.0 & 51.0 & PN-R-04020: 1994 + Az1: 2004 \\
\hline pH KCl & - & 4.3 & 6.7 & PN-ISO10390:1997P \\
\hline${ }^{*}$ the particle size was determined with the laser diffraction method (according to analytical procedures used in \\
accredited laboratories of chemical and agricultural stations).
\end{tabular}

The experiment was set up on $12 \mathrm{~m}^{2}$ plots using the randomized block method with three replications. In the experiment (both soils), five levels of nitrogen fertilization were applied: $0,30,60,90$, and $120 \mathrm{~kg} \mathrm{~N}$ per ha. Nitrogen (34\% ammonium nitrate) was used in two doses: After the beginning of plant vegetation in spring and in the phase of inflorescence shoot formation. The same fertilization with phosphorus (single superphosphate $80 \mathrm{~kg} \mathrm{P} \cdot \mathrm{ha}^{-1}$ ) and potassium (potassium salt $120 \mathrm{~kg} \mathrm{~K} \cdot \mathrm{ha}^{-1}$ ) was applied in both plots in autumn. 
The plants were weeded manually during the experiment. No diseases and pests of meadow arnica were found during the vegetation period; therefore, no plant protection agents were used.

\subsection{Plant Material}

Arnica chamissonis flower heads were collected successively from the entire plot in the full flowering phase (ray florets open; half of the disc florets open) in the same experimental units in the following years-2017-2019. After each harvest, fresh flower heads were weighed and dried in a drying room at $40{ }^{\circ} \mathrm{C}$. After drying, the samples were weighed to determine the dry weight of the raw material. Next, the Arnicae anthodium raw material intended for laboratory analyses was stored in paper bags at room temperature.

\subsection{Chemical Analyses}

\subsubsection{Sesquiterpene Lactones}

Sesquiterpene lactones (SLs) were determined with the chromatographic method described in Polish Pharmacopoeia VIII [78]. The results are presented as $\%$ of the sum of sesquiterpene lactones calculated as dihydrohelenalin tiglinate equivalents.

\subsubsection{Flavonoids}

The content of flavonoids ( $\mathrm{Fs}$ ) expressed as quercetin equivalents were determined with the spectrophotometric method specified by Polish Pharmacopoeia VI [79].

\subsubsection{Essential Oil}

The percentage of essential oils (EO) was determined with the hydrodistillation method described in Polish Pharmacopoeia VI [79].

All chemical analyses were performed in triplicate.

\subsection{Theoretical Yield of Metabolites per Unit Area}

The yield of metabolites (SLs, Fs, EO) was expressed in $\mathrm{kg} \cdot \mathrm{ha}^{-1}$. The results were used to calculate the yield of SLs, Fs, and EO per 1 ha (yield of flower heads $\times$ content of metabolites).

\subsection{Statistical Analysis}

The multi-way analysis of variance (ANOVA) and subsequent Tukey tests were used. The differences were considered significant at $p<0.05$. Pearson's correlation coefficients were calculated to evaluate the significance of the relationships between the variables. The statistical analyses were carried out using the Statistica 6.0 software. Variation in the relationship between the studied characteristics was explored using principal component analysis (PCA). PCA is a common technique used to describe patterns of variation within multi-dimensional datasets [80]. Before analysis, all data were centered and logtransformed. The analyses were carried out using the statistical package (MVSP) program version 3.1. [81].

\subsection{Meteorological Conditions}

Favorable weather conditions prevailed during the establishment of the experiment (2016) when the meadow arnica was planted. May was characterized by moderate air temperature values $\left(14.4^{\circ} \mathrm{C}\right)$, and the precipitation in February, March, April, and May ensured proper moisture of the soil; therefore, $100 \%$ of the plants survived (Figure 1). 


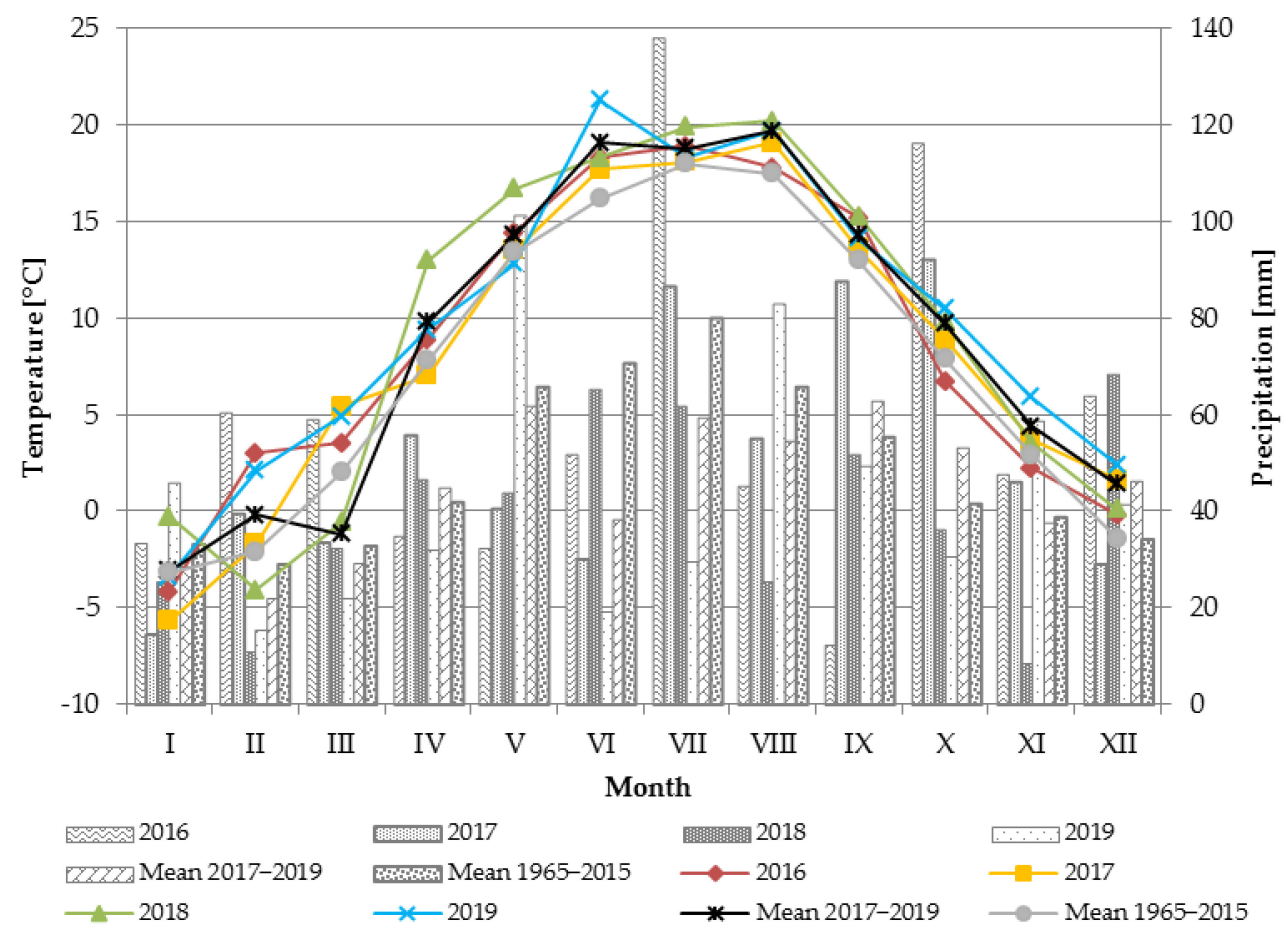

Figure 1. Air temperature and precipitation in the 2016-2019 growing seasons compared with the mean values (1965-2015); data provided by the Lublin-Radawiec meteorological station (Institute of Meteorology and Water Management-National Research Institute).

The thermal conditions fluctuated considerably during the study period (2017-2019) (Figure 1). The mean annual air temperature in this period was $9.2^{\circ} \mathrm{C}$, which was $1.5^{\circ} \mathrm{C}$ higher than the multiyear mean (1965-2015). The highest average annual air temperature $\left(9.8^{\circ} \mathrm{C}\right)$ was recorded in the third study year, i.e., 2019. In turn, 2017 had a mean temperature of $8.4^{\circ} \mathrm{C}$, which was the coldest year. Plant growth and yields are largely dependent on the weather conditions prevailing during the growing season. The mean temperature in the vegetation period (April-October) in the years of flower head harvesting (2017-2019) was $15.1^{\circ} \mathrm{C}$, which was $1.7^{\circ} \mathrm{C}$ higher than the multiyear mean. The highest mean temperature during the growing season was recorded in the second study year (2018); it was $1.1^{\circ} \mathrm{C}$ higher than the mean value in $1965-2015$. The lowest mean temperature during the growing season was recorded in 2017 ; the mean temperature $\left(14.0^{\circ} \mathrm{C}\right)$ was $1.1^{\circ} \mathrm{C}$ lower than the multiyear value.

The mean annual precipitation rate during the study (2017-2019) was $540.5 \mathrm{~mm}$, and this value was $50.7 \mathrm{~mm}$ lower than the multiyear mean value (Figure 1). The lowest amount of precipitation was recorded in 2018 (the second year of the study), characterized by an over $112 \mathrm{~mm}$ decline in its rate in comparison with the mean value for 1965-2015. In the years of flower head harvesting, the vegetation seasons (April-October) were characterized by very diverse precipitation sums. The highest rainfall rate during the growing season was recorded in 2017 (448.4 mm), while 2018 and 2019 were characterized by similar values, i.e., 332.3 and $346.4 \mathrm{~mm}$, respectively (by 89.9 and 75.8 lower than the multiyear sum).

The thermal and moisture conditions during meadow arnica flowering are important for the yield and quality of the raw material. The meadow arnica in Poland flowers from the end of May to the end of the second ten days of June [7]. The weather conditions in this phase varied during the three-year study period but were generally favorable and ensured high yields of flower heads. The warm and moderately humid year 2017 turned out to be the most favorable for arnica plant growth and development. It was characterized by an appropriate distribution of precipitation during the period of intensive plant growth (April, May); hence, the weather conditions contributed to the high yields of the raw material. 


\section{Results and Discussion}

The results of the statistical analysis showed a statistically significant main effect of the soil type (S), nitrogen fertilization $(\mathrm{N})$, and years $(\mathrm{Y})$ on the content of all analyzed metabolites. In the case of the studied chemical compounds, a statistically significant effect of the $\mathrm{S} \times \mathrm{N}$ interactions, $\mathrm{S} \times \mathrm{Y}$ interactions, and $\mathrm{N} \times \mathrm{Y}$ interactions on all analyzed metabolites was confirmed. An effect of the $\mathrm{S} \times \mathrm{N} \times \mathrm{Y}$ interactions on sesquiterpene lactones and flavonoids was found (Table 2).

Table 2. Main effects of the experimental factors on the yield of flower heads (YFH) and the content of sesquiterpene lactones (SLs), flavonoids (Fs), and essential oils (EO) in the flower heads of A. chamissonis.

\begin{tabular}{ccccc}
\hline Characteristics & YFH & SLs & Fs & EO \\
\hline Factors & & & & \\
Soil type (S) & $\mathrm{F}=300.4 p<0.001$ & $\mathrm{~F}=20.4 p<0.001$ & $\mathrm{~F}=0.9 p=0.004$ & $\mathrm{~F}=101.6 p<0.001$ \\
Nitrogen (N) & $\mathrm{F}=113.8 p<0.001$ & $\mathrm{~F}=62.1 p<0.001$ & $\mathrm{~F}=61.8 p<0.001$ & $\mathrm{~F}=116.6 p<0.001$ \\
Years (Y) & $\mathrm{F}=618.3 p<0.001$ & $\mathrm{~F}=187.4 p<0.001$ & $\mathrm{~F}=188.7 p<0.001$ & $\mathrm{~F}=127.7 p<0.001$ \\
$\mathrm{~S} \times \mathrm{N}$ & $\mathrm{F}=4.4 p=0.004$ & $\mathrm{~F}=2.6 p=0.046$ & $\mathrm{~F}=23.7 p<0.001$ & $\mathrm{~F}=5.6 p<0.001$ \\
$\mathrm{~S} \times \mathrm{Y}$ & $\mathrm{F}=19.7 p<0.001$ & $\mathrm{~F}=4.3 p=0.019$ & $\mathrm{~F}=37.7 p<0.001$ & $\mathrm{~F}=10.2 p<0.001$ \\
$\mathrm{~N} \times \mathrm{Y}$ & $\mathrm{F}=5.7 p<0.001$ & $\mathrm{~F}=5.3 p<0.001$ & $\mathrm{~F}=6.2 p<0.001$ & $\mathrm{~F}=2.1 p=0.049$ \\
$\mathrm{~S} \times \mathrm{N} \times \mathrm{Y}$ & $\mathrm{F}=0.7 p=0.688$ & $\mathrm{~F}=5.3 p<0.001$ & $\mathrm{~F}=7.0 p<0.001$ & $\mathrm{~F}=1.6 p=0.133$ \\
\hline
\end{tabular}

As shown by literature data, the yield of meadow arnica flower heads (YFH) in eastern Poland varies widely from approximately 404 to $1300 \mathrm{~kg} \cdot \mathrm{ha}^{-1}[37,82]$. In the present study, a significantly higher yield of flower heads was obtained in the loamy soil than in the sandy soil variants (1310.3 and $1029.5 \mathrm{~kg} \cdot \mathrm{ha}^{-1}$, respectively). The yields were higher than values reported in previous studies $[37,82]$, and their magnitude was significantly influenced by the experimental factors (Table 2, Figure 2). The largest yield of Arnicae anthodium $\left(1956.0 \mathrm{~kg} \cdot \mathrm{ha}^{-1}\right)$ was recorded in the second year of cultivation (2017) on the loamy soil in plots fertilized with a nitrogen dose of $120 \mathrm{~kg} \cdot \mathrm{ha}^{-1}$. In turn, the lowest yields were obtained in the fourth year of cultivation (2019) in the control SS variant $\left(545.0 \mathrm{~kg} \cdot \mathrm{ha}^{-1}\right)$.

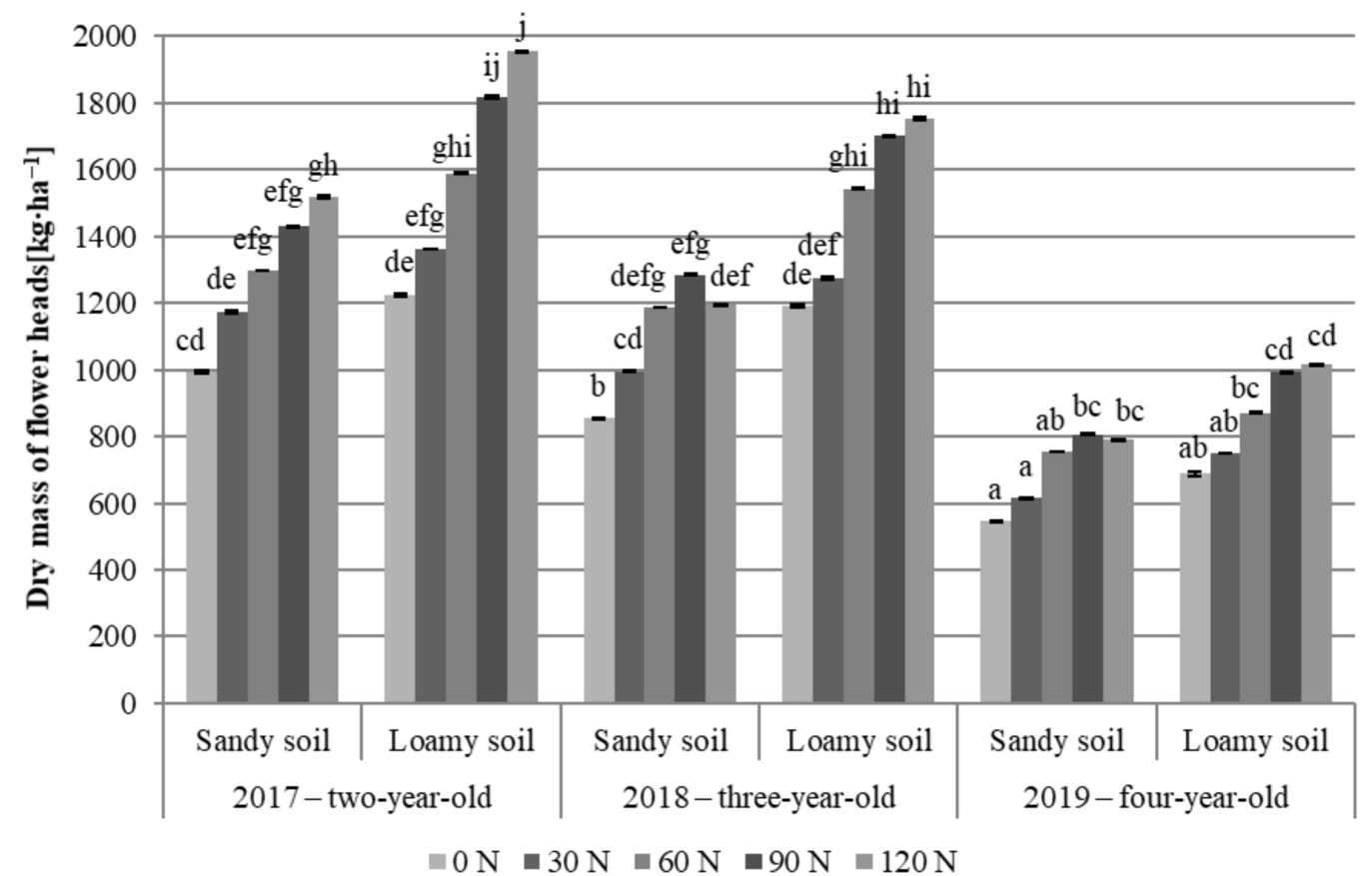

Figure 2. Yield of $A$. chamissonis flower heads depending on the experimental factors; $0 \mathrm{~N}, 30 \mathrm{~N}$, $60 \mathrm{~N}, 90 \mathrm{~N}, 120 \mathrm{~N}$-nitrogen doses $\left(\mathrm{kg} \cdot \mathrm{ha}^{-1}\right)$. Values designated by different letters are significantly different $(p=0.05)$ (Tukey test, $p<0.05)$. 
In both soil variants, the highest yield of flower heads was obtained in the second year of cultivation (2017); it was in the range from 1225 to $1956 \mathrm{~kg} \cdot \mathrm{ha}^{-1}$ in the loamy soil variants and from 995 to $1518 \mathrm{~kg} \cdot \mathrm{ha}^{-1}$ in the sandy soil (lower by $19.3 \%$ ). In the third year of cultivation, the value of the yield of flower heads was lower by 6.1 and $14.0 \%$, respectively. In the fourth year, the yields decreased significantly (by 17.6 and $45.4 \%$, respectively, compared to the year with the highest yields), which was especially noticeable in the sandy soil variants (Figure 2). Similar results were presented by other authors $[37,82,83]$.

The nitrogen fertilization applied in all the study years increased the yield of flower heads (Table 2, Figure 2). In the second and third years, the meadow arnica cultivated in the sandy soil variants had significantly higher yields in plots fertilized with $60 \mathrm{~kg} \mathrm{~N} \cdot \mathrm{ha}{ }^{-1}$, compared to the control. In the loamy soil plots, the increase in the $\mathrm{N}$ dose from 0 to $90 \mathrm{~kg} \cdot \mathrm{ha}^{-1}$ elevated the flower head yield in the two-year-old plants (2017). In turn, the yields increased significantly up to the dose of $60 \mathrm{~kg} \mathrm{~N} \cdot \mathrm{ha}^{-1}$ in the third year of cultivation. In the fourth year of plant growth on both soils, a significant increase in the yield was obtained after applying $90 \mathrm{~kg} \mathrm{~N} \cdot \mathrm{ha}^{-1}$ in comparison with the control. The higher amounts of nitrogen (90 and $120 \mathrm{~kg} \mathrm{~N} \cdot \mathrm{ha}^{-1}$ ) used in the present study caused an increase in the yield of flower heads, but the differences in the yields were not confirmed statistically (Figure 2).

Literature data report an increase in the weight of flower heads produced by Chamomilla recutita (L.) Rausch. and Chrysanthemum indicum L. with increasing nitrogen doses [67,69,84]. As shown by Giannoulis et al. [84], using 80 and $160 \mathrm{~kg} N \cdot \mathrm{ha}^{-1}$ in experimental plots contributed to a significant increase in the yield of chamomile flower heads compared to the nitrogen-unfertilized control. Nitrogen fertilization was found to exert a positive effect on the yields of other medicinal species from the family Asteraceae. In Tagetes erecta L., a two-fold increase in the nitrogen dose (from 100 to $200 \mathrm{~kg} \mathrm{~N} \cdot \mathrm{ha}^{-1}$ ) contributed to an over 30\% increase in the inflorescence yield [85]. In turn, Orange King and Tokaj cultivars of the marigold produced on average $12 \%$ and $9 \%$ higher weight of flower heads with each additional dose of $40 \mathrm{~kg} \mathrm{~N} \cdot \mathrm{ha}^{-1}[57,58]$.

The type of soil and nitrogen fertilization significantly modified the percentage content of sesquiterpene lactones in the analyzed material (Table 2). Their content in the meadow arnica flower heads ranged from 0.31 to $0.51 \%$ in the sandy soil variants and from 0.32 to $0.56 \%$ in the loamy soil (Figure 3). In most cases, the flower heads obtained in the present experiment met the Polish Pharmacopoeia XI [86] standards for Arnicae flos, i.e., the minimum content of sesquiterpene lactones of $0.40 \%$. These standards were met by the flower heads harvested from the four- (2019) and three-year-old (2018) plants growing on both soils fertilized with $60-120 \mathrm{~kg} \mathrm{~N} \cdot \mathrm{ha}^{-1}$.

The highest content of sesquiterpene lactones was detected in meadow arnica flower heads harvested from the three- (2018) and four-year-old (2019) plants growing on loamy soil fertilized with the highest nitrogen dose of $120 \mathrm{~kg} \mathrm{~N} \cdot \mathrm{ha}^{-1}(0.56$ and $0.55 \%$, respectively). In turn, the lowest content of the compounds was determined in the flower heads from the two-year-old control plants (2017) grown on the sandy soil (0.31\%). In both soil variants, the lowest content of sesquiterpene lactones was found in the raw material collected from the two-year-old plants (2017), regardless of nitrogen fertilization. The raw material harvested from plants grown in the loamy soil variants was characterized by a significantly higher concentration of sesquiterpene lactones compared to plants growing on the sandy soil (Table 2, Figure 3). A similar level of sesquiterpene lactones was reported by Olesińska and Sugier [37], whereas substantially lower contents were demonstrated by Ivanova et al. [87] and Kimel et al. [27]. 


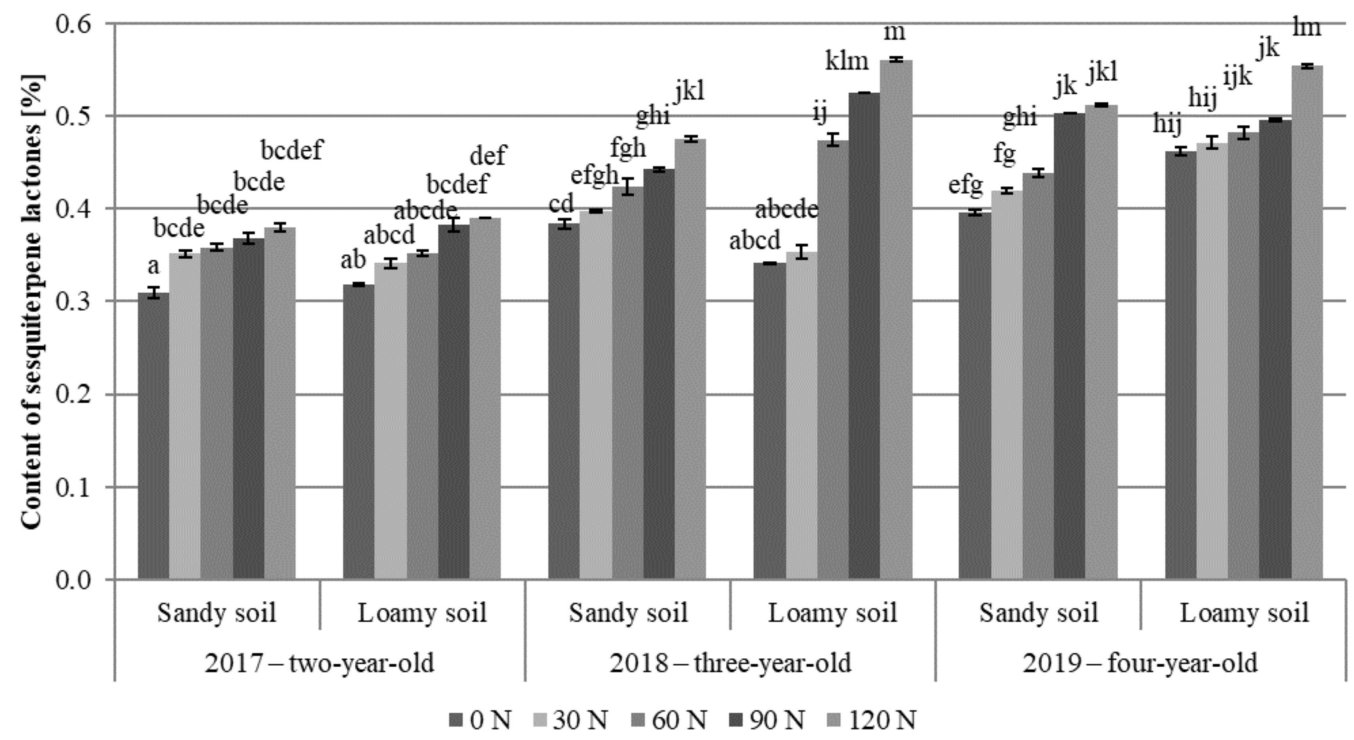

Figure 3. Content of sesquiterpene lactones in A. chamissonis flower heads depending on the experimental factors; $0 \mathrm{~N}, 30 \mathrm{~N}, 60 \mathrm{~N}, 90 \mathrm{~N}, 120 \mathrm{~N}$-nitrogen doses $\left(\mathrm{kg} \cdot \mathrm{ha}^{-1}\right)$. Values designated by different letters are significantly different $(p=0.05)$ (Tukey test, $p<0.05)$.

In both soil variants, the content of sesquiterpene lactones in the flower heads was significantly higher in the plots fertilized with 90 and $120 \mathrm{~kg} \mathrm{~N} \cdot \mathrm{ha}^{-1}$ compared to the control (Table 2, Figure 3). There are no available literature reports on the effect of nitrogen fertilization on the content of sesquiterpene lactones in the meadow arnica. In other herbal plants, the information on the impact of nitrogen on the content of sesquiterpene lactones in the raw material is not explicit. Kim and Lee [69] reported a nitrogen fertilization-induced decrease in the concentration of one of the sesquiterpene lactones in Chrysanthemum indicum flowers from 0.87 to $0.75 \mathrm{~g}$ cumambrin $\mathrm{A} \mathrm{kg} \cdot \mathrm{d} \cdot \mathrm{w}^{-1}$ (fertilization with 0 and $300 \mathrm{~kg} \mathrm{~N} \cdot \mathrm{ha}^{-1}$, respectively). Increasing doses of nitrogen stimulated Artemisia annua L. plants to biosynthesize nearly $50 \%$ higher amounts of artemisinin [88].

The content of flavonoids in the meadow arnica flower heads was correlated significantly with the experimental factors (Table 2, Figure 4). The percent content of flavonoids in the raw material ranged from 0.41 to $0.51 \%$ in the sandy soil variants and from 0.38 to $0.57 \%$ in the loamy soil (Figure 4). The highest content of flavonoids was found in the flower heads of the three-year-old plants (2018) growing on the loamy soil fertilized with 60 and $90 \mathrm{~kg} \mathrm{~N} \cdot \mathrm{ha}^{-1}$ (0.56 and $0.57 \%$, respectively). In turn, the lowest concentration of flavonoids was detected in the flower heads of the two-year-old plants (2017) growing in the loamy soil control plot $(0.38 \%)$. The present study showed a significant effect of nitrogen fertilization on the flavonoid content in the flower heads. In both soil variants, a significantly higher level of flavonoids in the flower heads, compared to the control, was obtained after applying $60 \mathrm{~kg} \mathrm{~N} \cdot \mathrm{ha}^{-1}$ throughout the study. A further increase in the nitrogen dose (up to 90 and $120 \mathrm{~kg} \mathrm{~N} \cdot \mathrm{ha}^{-1}$ ) did not influence the flavonoid content in the flower heads. In turn, in the case of the two-year-old plants grown on the sandy soil and the three-year-old plants grown on the loamy soil, the increase resulted in a decline in the concentration of this metabolite in the flower heads (Figure 4). 


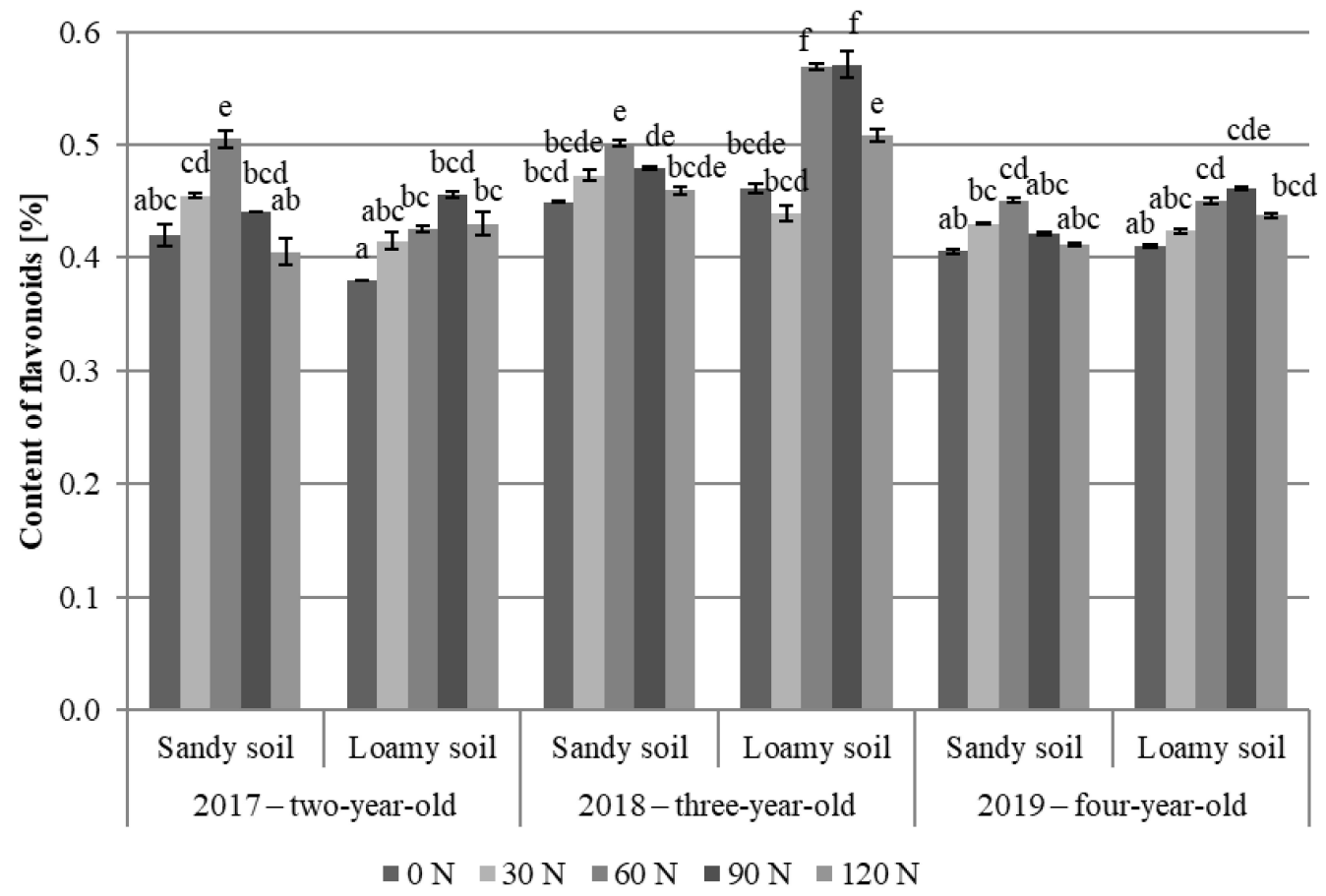

Figure 4. Content of flavonoids in A. chamissonis flower heads depending on the experimental factors; $0 \mathrm{~N}, 30 \mathrm{~N}, 60 \mathrm{~N}, 90 \mathrm{~N}, 120 \mathrm{~N}$-nitrogen doses $\left(\mathrm{kg} \cdot \mathrm{ha}^{-1}\right)$. Values designated by different letters are significantly different $(p=0.05)$ (Tukey test, $p<0.05)$.

As shown by literature data, the content of flavonoids in meadow arnica raw material ranges from 0.11 to $0.76 \%[37,82,89]$, which indicates agreement of the results of the present study with this range. In sesquiterpene lactones, there are no available literature reports on the effect of nitrogen fertilization on the content of flavonoids in the meadow arnica. Similar findings of the effect of nitrogen fertilization on the flavonoid content have been described in a study of summer savory (Satureja hortensis L.), where $40 \mathrm{~kg} \cdot \mathrm{ha}^{-1}$ was the most favorable nitrogen dose [90]. There is no clear information on the impact of nitrogen on the content of flavonoids in herb plants from the family Asteraceae. Tshivhandekano et al. [91] reported that increasing nitrogen doses stimulated the synthesis of flavonoid compounds in Athrixia phylicoides DC., with the highest increase in quercetin content induced by using $75 \mathrm{~kg} \mathrm{~N} \cdot \mathrm{ha}^{-1}$. A further increase in nitrogen doses led to a significant decrease in the concentration of flavonoids, as in the case of the meadow arnica. In turn, it was shown that marigold flower heads contained the highest content of flavonoids in control plots $[57,58]$.

The content of essential oils in the meadow arnica flower heads analyzed in the present study ranged from 0.14 to $0.19 \%$ (Figure 5), which agrees with other literature results $[10,37]$. In flavonoids and sesquiterpene lactones, significantly higher content of essential oils was determined in the flower heads of plants grown in the loamy soil variants, which is consistent with literature data [10]. In sesquiterpene lactones, the flower heads of the four-year-old plants had the highest content of essential oils (2019). Nitrogen fertilization significantly modified their content in the raw material. In all study years, a significant increase in the essential oil content in the flower heads collected from the loamy soil variants, compared to the control, was noted after applying $60 \mathrm{~kg} N \cdot \mathrm{ha}^{-1}$. No significant increase in the essential oil content was noted after fertilization with the higher $\mathrm{N}$ doses (90 and $120 \mathrm{~kg} \mathrm{~N} \cdot \mathrm{ha}^{-1}$ ). Similar relationships were found for the two- and four-year-old plants in the sandy soil variants. In turn, in the third year of cultivation, a significant increase in the essential oil content was achieved after applying $90 \mathrm{~kg} \mathrm{~N} \cdot \mathrm{ha}^{-1}$ (Figure 5). 


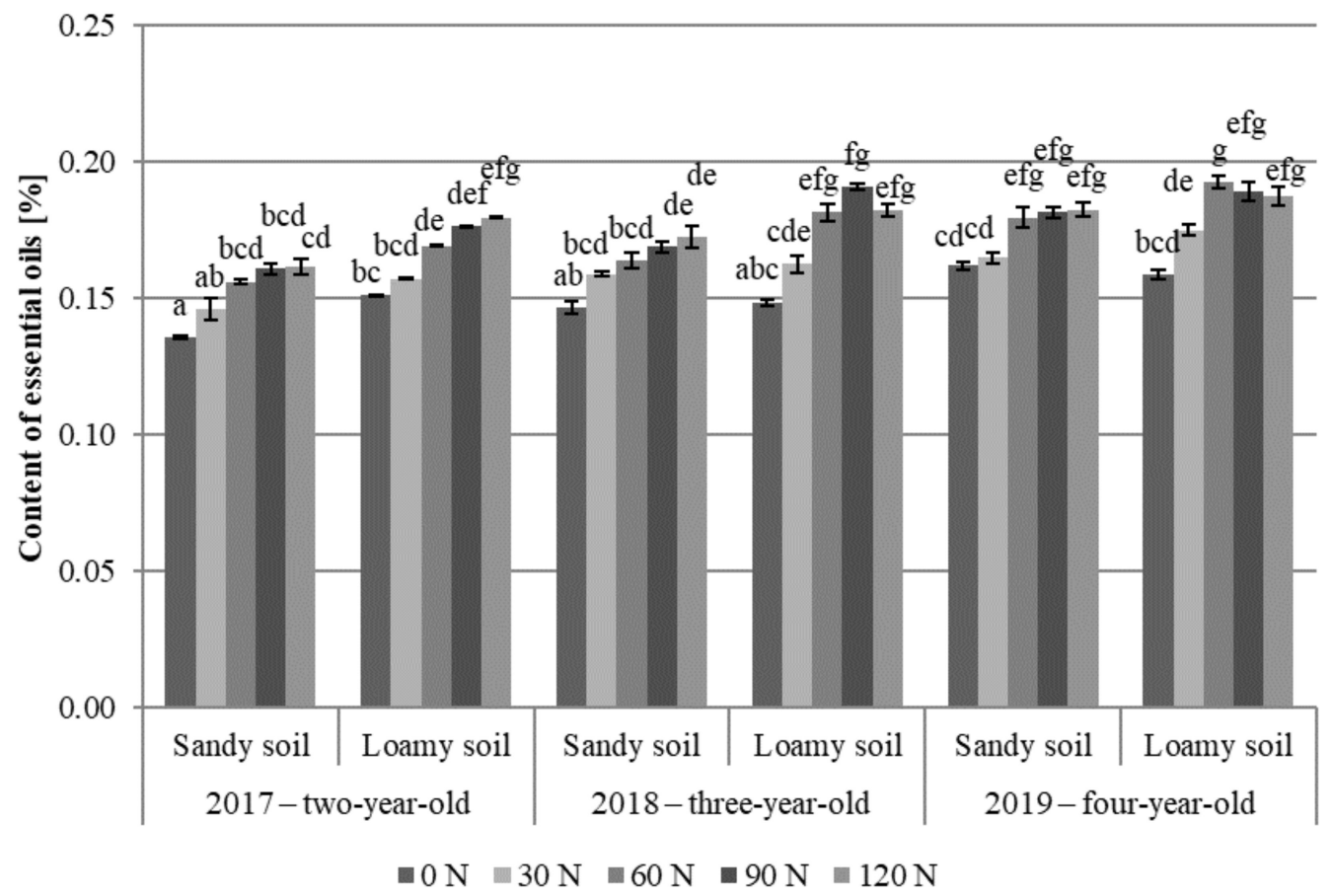

Figure 5. Content of essential oils in A. chamissonis flower heads depending on the experimental factors; $0 \mathrm{~N}, 30 \mathrm{~N}, 60 \mathrm{~N}, 90 \mathrm{~N}, 120 \mathrm{~N}$-nitrogen doses $\left(\mathrm{kg} \cdot \mathrm{ha}^{-1}\right)$. Values designated by different letters are significantly different $(p=0.05)$ (Tukey test, $p<0.05)$.

Literature data indicate that nitrogen fertilization affects the content of essential oils in various raw materials. A beneficial effect of nitrogen fertilization was demonstrated in the cases of summer savory [51,90], marigold [57,58], lemon verbena (Lippia citriodora Kunth.) [53], rosemary (Rosmarinus officinalis L.) [54], and sage (Salvia officinalis L.) [52]. Chamomile plants exhibited ambiguous responses to increasing nitrogen doses. Foladvand et al. [55] reported that an increase in the nitrogen dose to $100 \mathrm{~kg} \cdot \mathrm{ha}^{-1}$ caused a $16.5 \%$ decrease in the essential oil concentration, compared to raw material from the control plot. Different data were presented by Giannoulis et al. [84], who noted an increase in the essential oil content with increasing nitrogen doses, i.e., chamomile flower heads obtained from plots fertilized with $160 \mathrm{~kg} \mathrm{~N} \cdot \mathrm{ha}^{-1}$ contained $15.6 \%$ higher levels of essential oils than plants from the control plot.

The yield of sesquiterpene lactones, flavonoids, and essential oils per 1 ha varied significantly depending on the experimental factors (Table 3). The most favorable results of the yield of the active substances were obtained in the meadow arnica cultivated in the loamy soil variants. During the three study years, plants cultivated in this soil produced on average $5.63 \mathrm{~kg}$ of sesquiterpene lactones, $6.06 \mathrm{~kg}$ of flavonoids, and $2.28 \mathrm{~kg}$ of essential oils. In turn, $4.18 \mathrm{~kg}$ of sesquiterpene lactones, $4.64 \mathrm{~kg}$ of flavonoids, and $1.67 \mathrm{~kg}$ of essential oils were obtained in the sandy soil variants (Table 3). Literature reports indicate lower yields of these metabolites, i.e., approx. $3.7 \mathrm{~kg}$ of sesquiterpene lactones, $4.4 \mathrm{~kg}$ of flavonoids, and $1.7 \mathrm{~kg}$ of essential oils $\cdot \mathrm{ha}^{-1}[10,37]$. The present study showed a significant effect of nitrogen fertilization on the yield of sesquiterpene lactones, flavonoids, and essential oils. High values were obtained in the yields of sesquiterpene lactones and essential oils at the doses of $90-120 \mathrm{~kg} \mathrm{~N} \cdot \mathrm{ha}^{-1}$ and the yield of flavonoids at the doses of $60-90 \mathrm{~N} \cdot \mathrm{ha}^{-1}$. 
Table 3. The yield of sesquiterpene lactones, flavonoids, and essential oil per ha ${ }^{-1}$ depending on the experimental factors; $0 \mathrm{~N}, 30 \mathrm{~N}, 60 \mathrm{~N}, 90 \mathrm{~N}, 120 \mathrm{~N}$-nitrogen doses $\left(\mathrm{kg} \cdot \mathrm{ha}^{-1}\right)$. Values designated by different letters are significantly different $(p=0.05)$ (Tukey test, $p<0.05)$.

\begin{tabular}{|c|c|c|c|c|c|c|}
\hline \multirow{2}{*}{$\begin{array}{c}\text { Nitrogen } \\
\text { Doses } \\
\left(\mathrm{kg} \cdot \mathrm{ha}^{-1}\right)\end{array}$} & \multicolumn{3}{|c|}{ Sandy Soil } & \multicolumn{3}{|c|}{ Loamy Soil } \\
\hline & $\begin{array}{c}2017 \\
\text { II }\end{array}$ & $\begin{array}{c}2018 \\
\text { III }\end{array}$ & $\begin{array}{l}2019 \\
\text { IV }\end{array}$ & $\begin{array}{c}2017 \\
\text { II }\end{array}$ & $\begin{array}{c}2018 \\
\text { III }\end{array}$ & $\begin{array}{l}2019 \\
\text { IV }\end{array}$ \\
\hline \multicolumn{7}{|c|}{ Sesquiterpene lactones, $\mathrm{kg}$ dihydrohelenalin tiglinate $\cdot \mathrm{ha}^{-1}$} \\
\hline 0 & $3.1^{b c} \pm 0.11$ & $3.3^{\mathrm{bc}} \pm 0.09$ & $2.2^{\mathrm{a}} \pm 0.03$ & $3.9^{\text {def }} \pm 0.04$ & $4.1^{\text {def }} \pm 0.01$ & $3.2^{b c} \pm 0.21$ \\
\hline 30 & $4.1^{\text {de }} \pm 0.08$ & $3.9^{\text {de }} \pm 0.03$ & $2.6^{\mathrm{ab}} \pm 0.28$ & $4.7^{\mathrm{efg}} \pm 0.12$ & $4.5^{\mathrm{ef}} \pm 0.18$ & $3.5^{\mathrm{cd}} \pm 0.10$ \\
\hline 60 & $4.7^{\mathrm{efg}} \pm 0.27$ & $5.0^{\mathrm{fgh}} \pm 0.21$ & $3.3^{\mathrm{bc}} \pm 0.57$ & $5.6^{\mathrm{gh}} \pm 0.61$ & $7.3^{\mathrm{i}} \pm 0.21$ & $4.2^{\mathrm{de}} \pm 0.18$ \\
\hline 90 & $5.3^{\mathrm{fgh}} \pm 0.16$ & $5.7^{\mathrm{h}} \pm 0.04$ & $4.1^{\text {de }} \pm 0.01$ & $7.0^{\mathrm{i}} \pm 0.27$ & $8.9^{\mathrm{j}} \pm 0.01$ & $4.9^{\mathrm{fgh}} \pm 0.02$ \\
\hline 120 & $5.8^{\mathrm{h}} \pm 0.12$ & $5.7^{\mathrm{h}} \pm 0.80$ & $4.0^{\text {de }} \pm 0.02$ & $7.6^{\mathrm{i}} \pm 0.02$ & $9.8^{k} \pm 0.37$ & $5.6^{\mathrm{gh}} \pm 0.04$ \\
\hline \multicolumn{7}{|c|}{$\begin{array}{l}\text { ANOVA results: Soil type }(\mathrm{S})-\mathrm{F}=713.57, p<0.001 ; \text { Nitrogen }(\mathrm{N})-\mathrm{F}=471.05, p<0.001 ; \text { Years }(\mathrm{Y})-\mathrm{F}=524.98, p<0.001 \\
\quad \mathrm{~S} \times \mathrm{N}-\mathrm{F}=36.03, p<0.001 ; \mathrm{S} \times \mathrm{Y}-\mathrm{F}=49.72, p<0.001 ; \mathrm{N} \times \mathrm{Y}-\mathrm{F}=22.58, p<0.001 ; \mathrm{S} \times \mathrm{N} \times \mathrm{Y}-\mathrm{F}=13.69, p<0.001\end{array}$} \\
\hline \multicolumn{7}{|c|}{ Flavonoids, $\mathrm{kg}$ quercetin $\cdot \mathrm{ha}^{-1}$} \\
\hline 0 & $4.2^{\mathrm{de}} \pm 0.01$ & $3.8^{\mathrm{bcd}} \pm 0.01$ & $2.2^{\mathrm{a}} \pm 0.02$ & $4.7^{\mathrm{e}} \pm 0.00$ & $5.5^{\mathrm{fgh}} \pm 0.11$ & $2.8^{\mathrm{ab}} \pm 0.01$ \\
\hline 30 & $5.3^{\mathrm{fg}} \pm 0.06$ & $4.7^{\text {ef }} \pm 0.09$ & $2.7^{\mathrm{ab}} \pm 0.01$ & $5.7^{\mathrm{fgh}} \pm 0.20$ & $5.6^{\mathrm{fgh}} \pm 0.17$ & $3.2^{b} \pm 0.03$ \\
\hline 60 & $6.6^{\mathrm{ij}} \pm 0.19$ & $6.0^{\text {ghi }} \pm 0.08$ & $3.4^{b c} \pm 0.03$ & $6.8^{\mathrm{j}} \pm 0.08$ & $8.8^{\mathrm{k}} \pm 0.08$ & $3.9^{\mathrm{cd}} \pm 0.04$ \\
\hline 90 & $6.3^{\text {hij }} \pm 0.00$ & $6.2^{\text {hij }} \pm 0.04$ & $3.4^{b c} \pm 0.02$ & $8.3^{k} \pm 0.10$ & $9.7^{1} \pm 0.39$ & $4.6^{\text {de }} \pm 0.02$ \\
\hline 120 & $6.2^{\text {ghij }} \pm 0.83$ & $5.5^{\mathrm{fg}} \pm 0.09$ & $3.3^{b} \pm 0.02$ & $8.4^{\mathrm{k}} \pm 0.39$ & $8.9^{k} \pm 0.19$ & $4.4^{\text {de }} \pm 0.04$ \\
\hline
\end{tabular}

ANOVA results: Soil type $(\mathrm{S})-\mathrm{F}=1077.42, p<0.001$; Nitrogen $(\mathrm{N})-\mathrm{F}=508.96, p<0.001$; Years $(\mathrm{Y})-\mathrm{F}=2147.6, p<0.001$; $\mathrm{S} \times \mathrm{N}-\mathrm{F}=60.4, p<0.001 ; \mathrm{S} \times \mathrm{Y}-\mathrm{F}=152.87, p<0.001 ; \mathrm{N} \times \mathrm{Y}-\mathrm{F}=33.12, p<0.001 ; \mathrm{S} \times \mathrm{N} \times \mathrm{Y}-\mathrm{F}=12.27, p<0.001$

\begin{tabular}{ccccccc}
\multicolumn{7}{c}{ Essential oils, kg oil $\cdot \mathrm{ha}^{-1}$} \\
0 & $1.4^{\mathrm{cd}} \pm 0.01$ & $1.3^{\mathrm{bc}} \pm 0.04$ & $0.9^{\mathrm{a}} \pm 0.02$ & $1.9^{\mathrm{gh}} \pm 0.01$ & $1.8^{\mathrm{fg}} \pm 0.03$ & $1.1^{\mathrm{b}} \pm 0.02$ \\
30 & $1.7^{\mathrm{fg}} \pm 0.09$ & $1.6^{\mathrm{ef}} \pm 0.02$ & $1.0^{\mathrm{b}} \pm 0.02$ & $2.1^{\mathrm{jk}} \pm 0.01$ & $2.1^{\mathrm{ij}} \pm 0.08$ & $1.3^{\mathrm{cd}} \pm 0.03$ \\
60 & $2.0^{\mathrm{ij}} \pm 0.02$ & $1.9^{\mathrm{hi}} \pm 0.07$ & $1.4^{\mathrm{cd}} \pm 0.06$ & $2.7^{\mathrm{m}} \pm 0.01$ & $2.8^{\mathrm{m}} \pm 0.10$ & $1.7^{\mathrm{fg}} \pm 0.04$ \\
90 & $2.3^{\mathrm{kl}} \pm 0.06$ & $2.2^{\mathrm{jk}} \pm 0.05$ & $1.5^{\mathrm{de}} \pm 0.04$ & $3.2^{\mathrm{n}} \pm 0.01$ & $3.3^{\mathrm{n}} \pm 0.03$ & $1.9 \mathrm{gh} \pm 0.07$ \\
120 & $2.5^{\mathrm{l}} \pm 0.08$ & $2.1^{\mathrm{ij}} \pm 0.10$ & $1.4^{\mathrm{de}} \pm 0.04$ & $3.5^{\mathrm{o}} \pm 0.01$ & $3.2^{\mathrm{n}} \pm 0.08$ & $1.9 \mathrm{gh} \pm 0.06$
\end{tabular}

ANOVA results: Soil type $(\mathrm{S})-\mathrm{F}=2967.3, p<0.001$; Nitrogen $(\mathrm{N})-\mathrm{F}=1335.9, p<0.001$; Years $(\mathrm{Y})-\mathrm{F}=2754.7, p<0.001$;

$\mathrm{S} \times \mathrm{N}-\mathrm{F}=73.3, p<0.001 ; \mathrm{S} \times \mathrm{Y}-\mathrm{F}=203.2, p<0.001 ; \mathrm{N} \times \mathrm{Y}-\mathrm{F}=59.3, p<0.001 ; \mathrm{S} \times \mathrm{N} \times \mathrm{Y}-\mathrm{F}=8.6, p<0.001$

II—two-year-old plants, III—three-year-old plants, IV—four-year-old plants.

Figure 6 shows the results of the PCA ordination of the samples. The eigenvalues of the first (4.28) and second (1.94) axes indicate the presence of two gradients, within which the samples are differentiated in terms of the examined traits. The first two axes explain $97.72 \%$ of the variability (61.17\% the first axis, $27.65 \%$ the second axis), which proves that the traits correlated with these axes are greatly important for interpreting the differentiation and correlations between these traits. The flavonoid content, yield of sesquiterpene lactones, yield of essential oils, yield of flavonoids, and yield of flower heads are clearly correlated with the first axis. The content of sesquiterpene lactones and essential oils is positively correlated with the second axis. The first axis presents the gradient of flavonoids, yield of sesquiterpene lactones, yield of essential oils, yield of flavonoids, and yield of flower heads, which implies that the value of these traits increases with the increasing nitrogen doses in both soil variants. The variation between the study years is evident as well. The highest flavonoid content and yield of sesquiterpene lactones were exhibited by samples collected in 2018 from the loamy soil (Figure 6). In turn, sesquiterpene lactones and essential oils were positively correlated with the second axis and with each other in the sandy soil and loamy soil variants (Tables 4 and 5). This indicates that the content of these compounds increased in the subsequent years and with the increase in nitrogen doses. The yield of sesquiterpene lactones and the yield of essential oils did not depend on the concentration of sesquiterpene lactones and essential oils but correlated with the increase in the yield of flower heads of plants from the sandy soil and loamy soil variants. In turn, the yield of flavonoids was influenced by both the concentration of flavonoids and the yield of flower heads (Tables 4 and 5). 


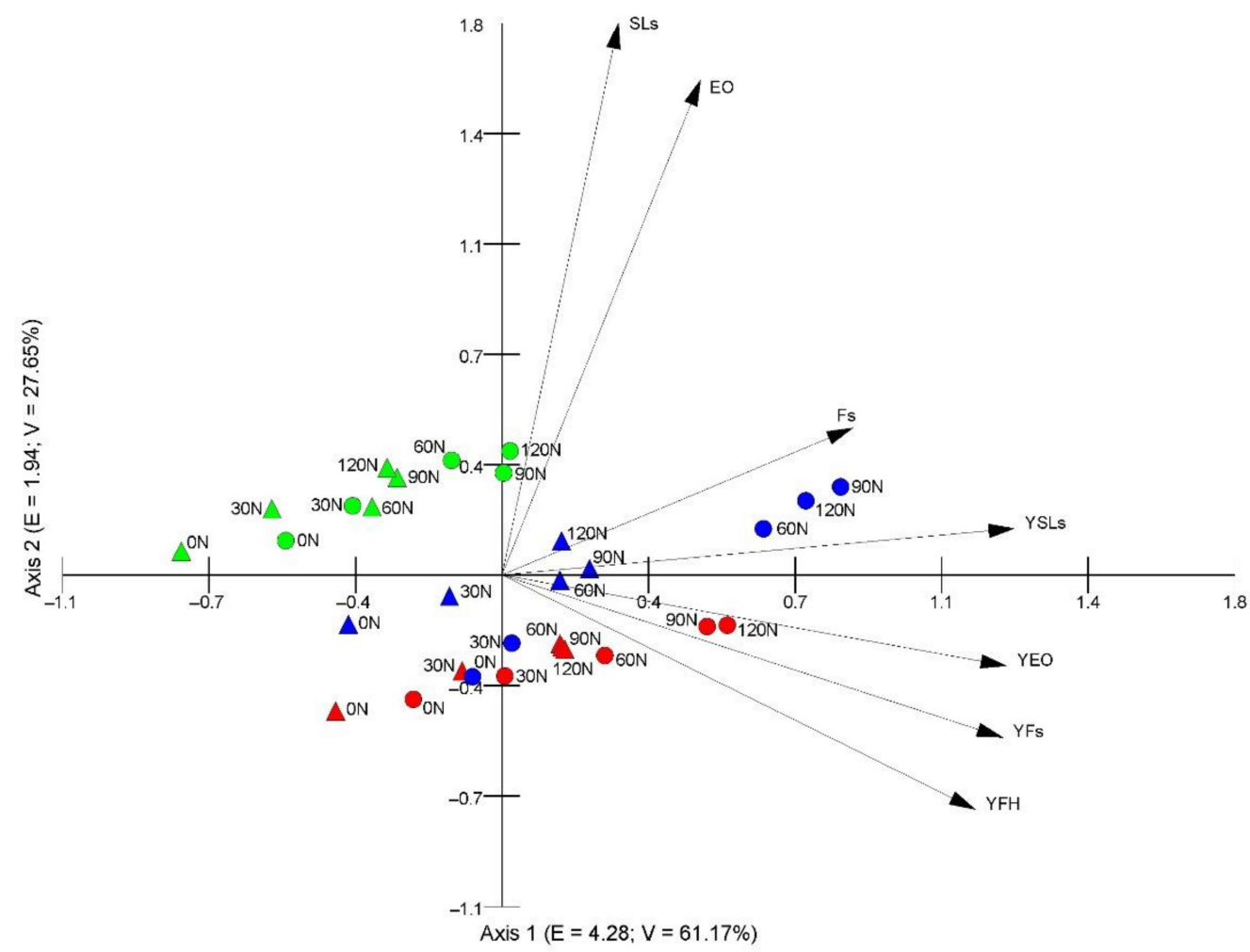

Figure 6. Principal component analysis (PCA) ordination diagram presenting the distribution of the samples based on mean values of the studied characteristics under the influence of nitrogen fertilization; E-eigenvalues, $\mathrm{V}$-percentage variance explained by the first two PCA axes, SLs—sesquiterpene lactones, Fs-flavonoids, EO-essential oils, YSLs-yield of sesquiterpene lactones, YFs-yield of flavonoids, YEO-yield of essential oils, YFH-yield of flower heads, $0 \mathrm{~N}-120 \mathrm{~N}$-nitrogen doses, circle-loamy soil, triangle—sandy soil, red color-2017, blue color-2018, green color-2019.

Table 4. Correlation coefficients for relationships between the studied traits of plants from the sandy soil during the three-year experiment $(n=24)$; bolded correlation coefficients are statistically significant. For explanations, see Figure 5.

\begin{tabular}{ccccccc}
\hline SLs & -0.31 & & & & & \\
Fs & 0.39 & -0.10 & & & & \\
EO & -0.30 & 0.89 & -0.13 & & & \\
YSLs & 0.88 & 0.15 & 0.39 & 0.10 & \\
YFs & 0.97 & -0.30 & 0.60 & -0.29 & 0.87 & \\
YEO & 0.96 & -0.07 & 0.37 & -0.04 & 0.96 & 0.94 \\
& YFH & SLs & Fs & EO & YSLs & YFs \\
\hline
\end{tabular}

Table 5. Correlation coefficients for relationships between the studied traits of plants from the loamy soil during the three-year experiment $(n=24)$; bolded correlation coefficients are statistically significant. For explanations, see Figure 5.

\begin{tabular}{ccccccc}
\hline SLs & -0.17 & & & & & \\
Fs & 0.41 & 0.54 & & & & \\
EO & 0.13 & 0.78 & 0.54 & & \\
YSLs & 0.82 & 0.41 & 0.71 & 0.52 & 0.92 & \\
YFs & 0.94 & 0.08 & 0.69 & 0.30 & 0.91 & 0.96 \\
YEO & 0.97 & 0.04 & 0.52 & 0.35 & YSLs & YFs \\
& YFH & SLs & Fs & EO & & \\
\hline
\end{tabular}




\section{Conclusions}

The meadow arnica is a relatively new species in field cultivation; hence, the research on the influence of agronomic factors on its yield and the content of the main active substances is incomplete and requires supplementation. The present study showed that both the soil type and the nitrogen fertilization had a significant effect on the raw material yield, as well as the content and yield of the main active substances. The cultivation of A. chamissonis on the loamy soil proved more beneficial, as higher flower head yields, higher levels of sesquiterpene lactones, flavonoids, and essential oils, and consequently higher yields of these metabolites were achieved. In turn, the varying levels of nitrogen fertilization can be considered an appropriate way to increase the production of Arnicae anthodium (the highest yields were obtained at doses of $60-90 \mathrm{~kg} \mathrm{~N} \cdot \mathrm{ha}^{-1}$ ) and modify the chemical composition of this raw material. The content of sesquiterpene lactones and essential oils increased in the subsequent years, along with the increase in nitrogen doses. In turn, the highest content of flavonoids was detected in the flower heads of the three-year-old plants. The yields of sesquiterpene lactones and essential oils did not depend on the concentration of metabolites, but positively correlated with the yield of flower heads in both sandy and loamy soils. In turn, the yield of flavonoids was modified by the concentration of flavonoids and the yield of flower heads.

As shown in the present study, the yield of flower heads and the yields of metabolites of this medicinal plant species indicate favorable climatic and edaphic conditions for cultivation in eastern Poland, where A. chamissonis is currently not cultivated. Nevertheless, given the increasing demand for Arnicae anthodium in recent year, both the more fertile loamy soils and the poorer sandy soils can be used for the cultivation of the species. Moreover, a wide range of pharmacologically active substances (sesquiterpene lactones, flavonoids, essential oils) can be produced in this region of Europe by producing raw materials in sustainable conditions to meet the demands of the herb market.

Author Contributions: Conceptualization, K.O. and D.S.; formal analysis, K.O. and D.S.; investigation, K.O. and D.S.; methodology, K.O. and D.S.; supervision, K.O. and D.S.; visualization, K.O. and D.S.; writing—original draft, K.O. and D.S.; writing—review and editing, K.O., D.S. and Z.K. All authors have read and agreed to the published version of the manuscript.

Funding: This research received no external funding.

Institutional Review Board Statement: Not applicable.

Informed Consent Statement: Not applicable.

Data Availability Statement: The data presented in this study are available on request from the corresponding author. The data are not publicly available due to ongoing unpublished research.

Conflicts of Interest: The authors declare no conflict of interest.

\section{References}

1. Maguire, B. A monograph of the genus arnica (Senecioneae, Compositae). Brittonia 1943, 4, 386-510.

2. Scoggan, H.J. The Flora of Canada. Part 4. Dicotyledoneae (Loasaceae to Compositae); National Museum of Natural Sciences Publications in Botany: Ottawa, ON, Canada, 1979.

3. Wenk, E. Wildflowers of the High Sierra and John Muir Trail; Wilderness Press: Birmingham, AL, USA, 2015 ; pp. 91-92.

4. Denver Botanic Gardens. Wildflowers of the Rocky Mountain Region; Timber Press Inc.: Portland, OR, USA, 2018 ; p. 416.

5. Johnson, R.L.; Andreson, V.J.; Yeankee, A.T.; Anderson, Z. Seed predation in wild populations of Chamisso arnica (Arnica chamissonis Less: Asteraceae) and new host records for Campiglossa snowi (Hering) (Diptera: Tephritidae). West. N. Am. Nat. 2017, 77, 14-21. [CrossRef]

6. Radanović, D.; Marković, T.; Antić-Mladenović, S.; Pljevljakušić, D.; Ristić, M.; Krivokuća-Dokić, D. Yield and quality of Arnica (Arnica montana and Arnica chamissonis var. foliosa) cultivated in Serbia. In Proceedings of the 1st International Scientific Conference on Medicinal, Aromatic and Spice Plants, Nitra, Slovakia, 5-6 December 2007; pp. 157-161.

7. Sugier, D. The flowering pattern of Arnica montana L. and A. chamissonis Less. under field cultivation conditions with successive flower head collection. Acta Agrobot. 2007, 60, 133-139. [CrossRef]

8. Judžentienè, A.; Būdienè, J. Analysis of the chemical composition of flower essential oils from Arnica montana of Lithuanian origin. Chemija 2009, 20, 190-194. 
9. Kowalski, R.; Sugier, D.; Sugier, P.; Kołodziej, B. Evaluation of the chemical composition of essential oils with respect to the maturity of flower heads of Arnica montana L. and Arnica chamissonis Less. cultivated for industry. Ind. Crop. Prod. 2015, 76, 857-865. [CrossRef]

10. Sugier, D.; Olesińska, K.; Sugier, P.; Wójcik, M. Chemical composition of essential oil from flower heads of Arnica chamissonis Less. under a nitrogen impact. Molecules 2019, 24, 4454. [CrossRef]

11. Gawlik-Dziki, U.; Świeca, M.; Sugier, D.; Cichocka, J. Seeds of Arnica montana and Arnica chamissonis as a potential source of natural antioxidants. Herba Pol. 2009, 55, 60-71.

12. Gawlik-Dziki, U.; Świeca, M.; Sugier, D.; Cichocka, J. Comparison of in vitro lipoxygenase, xanthine oxidase inhibitory and antioxidant activity of Arnica montana and Arnica chamissonis tinctures. Acta Sci. Pol. Hortorum Cultus 2011, 10, 15-27.

13. Korneck, D.; Schnittler, M.; Vollmer, I. Red list of pteridophyta and spermatophyta in Germany. In Red List of Endangered Plants in Germany; Ludwig, G., Schnittler, M., Eds.; Bundesamt für Naturschutz: Bonn, Germany, 1996; Volume 28, pp. 21-187.

14. Ekenäs, C. Phylogenies and Secondary Chemistry in Arnica (Asteraceae). Ph.D. Thesis, Faculty of Science and Technology, Uppsala University, Uppsala, Sweden, 2008; pp. 40-42.

15. Falniowski, A.; Bazos, I.; Hodálová, I.; Lansdown, R.; Petrova, A. Arnica montana. In IUCN 2012. IUCN Red List of Threatened Species, Version 2012.2; IUCN: Gland, Switzerland, 2012.

16. Sugier, P.; Kołos, A.; Wołkowycki, D.; Sugier, D.; Plak, A.; Sozinov, O. Evaluation of species inter-relations and soil conditions in Arnica montana L. habitats: A step towards active protection of endangered and high-valued medicinal plant species in NE Poland. Acta Soc. Bot. Pol. 2018, 87, 3592. [CrossRef]

17. Mardari, C.; Birsan, C.; Stefanache, C.; Schiopu, R.; Grigoras, V.; Balaes, T.; Tanase, C. Population structure and habitat characteristics of Arnica montana L. in the NE Carpathians (Romania). Tuexenia 2019, 39, 401-421. [CrossRef]

18. Sugier, P.; Sugier, D.; Sozinov, O.; Kołos, A.; Wołkowycki, D.; Plak, A.; Budnyk, O. Characteristics of plant communities, population features, and edaphic conditions of Arnica montana L. populations in pine forests of mid-eastern Europe. Acta Soc. Bot. Pol. 2019, 88, 3640. [CrossRef]

19. Kathe, W. Conservation of Eastern-European medicinal plants: Arnica montana in Romania. In Medicinal and Aromatic Plants: Agricultural, Cultivated, Ecological, Legal, Pharmacological and Social Aspects; Bogers, R.J., Craker, L.E., Dagmar, L., Eds.; Springer: Berlin/Heidelberg, Germany, 2006; Volume 17, pp. 203-211.

20. Pasquier, B.; Godin, M. L'arnica des montagnes, entre culture et cueillette. Jard. Fr. 2014, 630, 19-21. Available online: https: //www.jardinsdefrance.org/wp-content/uploads/jdf-medias/images/JdF630/JdF630_1F.pdf (accessed on 12 August 2021).

21. Stefanache, C.P.; Peter, S.; Meier, B.; Danila, D.; Tanase, C.; Wolfram, E. Phytochemical composition of Arnicae flos from wild populations in the northern area of the Romanian eastern Carpathians. Rev. Chim. 2015, 66, 784-787.

22. Leoni, V.; Borgonovo, G.; Giupponi, L.; Bassoli, A.; Pedrali, D.; Zuccolo, M.; Rodari, A.; Giorgi, A. Comparing Wild and Cultivated Arnica montana L. from the Italian Alps to Explore the Possibility of Sustainable Production Using Local Seeds. Sustainability 2021, 13, 3382. [CrossRef]

23. Nowak, T. Arnika nizinna-Uprawy w rejonie gostyńsko-leszczyńskim. Wiad. Zielar. 2002, 44, 18-19.

24. Nowak, K. (KAWON-HURT, Gostyń, Poland). Personal Communication, 2021.

25. Kromer, K.; Kreitschitz, A.; Kleinteich, T.; Gorb, S.N.; Szumny, A. Oil secretory system in vegetative organs of three Arnica taxa: Essential oil synthesis, distribution and accumulation. Plant Cell Physiol. 2016, 57, 1020-1037. [CrossRef]

26. Sugier, D.; Sugier, P.; Jakubowicz-Gil, J.; Winiarczyk, K.; Kowalski, R. Essential oil from Arnica montana achenes: Chemical characteristics and anticancer activity. Molecules 2019, 24, 4158. [CrossRef]

27. Kimel, K.; Krauze-Baranowska, M.; Godlewska, S.; Pobłocka-Olech, L. HPLC-DAD-ESI/MS comparison of the chemical composition of flowers from two Arnica species grown in Poland. Herba Pol. 2020, 66, 1-10. [CrossRef]

28. Sugier, P.; Jakubowicz-Gil, J.; Sugier, D.; Kowalski, R.; Gawlik-Dziki, U.; Kołodziej, B.; Dziki, D. Chemical characteristics and anticancer activity of essential oil from Arnica montana L. rhizomes and roots. Molecules 2020, 25, 1284. [CrossRef]

29. Cassells, A.C.; Walsh, C.; Belin, M.; Robin, J.R.; Lubrano, C. Establishment of a plantation from micropropagated Arnica chamissonis a pharmaceutical substitute for the endangered A. montana. Plant Cell Tissue Organ Cult. 1999, 56, 139-144. [CrossRef]

30. Gawlik-Dziki, U.; Świeca, M.; Sugier, D.; Cichocka, J. Comparison of antioxidant properties of infusions from different parts of Arnica montana and Arnica chamissonis var. foliosa Less. Herba Pol. 2010, 56, 59-68.

31. Oleszek, M.; Kozachok, S. Antioxidant activity of plant extracts and their effect on methane fermentation in bioreactors. Int. Agrophys. 2018, 32, 395-401. [CrossRef]

32. Olesińska, K. Antioxidant properties of Chamisso arnica (Arnica chamissonis Less.) water infusions. Agron. Sci. 2020, 75, 85-94. [CrossRef]

33. Lim, C.B.; Fu, P.Y.; Ky, N.; Zhu, H.S.; Feng, X.; Li, J.; Srinivasan, K.G.; Hamza, M.S.; Zhao, J. NF-kB p65 repression by the sesquiterpene lactone, helenalin, contributes to the induction of autophagy cell death. BMC Complement. Altern. Med. 2012, 12, 1-12. [CrossRef] [PubMed]

34. Ghasemali, S.; Nejati-Koshki, K.; Tafsiri, E.; Rahmati-Yamchi, M.; Akbarzadeh, A.; Alizadeh, E.; Abbasi, M.; Barkhordari, A.; Tozihi, M.; Kordi, S.; et al. Inhibitory effects of $\beta$-cyclodextrin-helenalin complexes on H-TERT gene expression in the T47D breast cancer cell line-Results of real time quantitative PCR. Asian Pac. J. Cancer Prev. 2013, 14, 6949-6953. [CrossRef] [PubMed] 
35. Russo, P.; Frustaci, A.; Del Bufalo, A.; Fini, M.; Cesario, A. From traditional European medicine to discovery of new drug candidates for the treatment of dementia and Alzheimer's disease: Acetylcholinesterase inhibitors. Curr. Med. Chem. 2013, 20, 976-983. [CrossRef]

36. Nichterlein, K. Arnica montana (mountain arnica): In vitro culture and the production of sesquiterpene lactones and other metabolites. Biotechnol. Agric. For. 1995, 33, 47-61. [CrossRef]

37. Olesińska, K.; Sugier, D. Row spacing and the term of harvest of flower heads as determinants of crop yield and chemical composition of raw material of chamisso arnica (Arnica chamissonis Less.). Acta Sci. Pol. Agric. 2020, 19, 83-95. [CrossRef]

38. Chadwick, M.; Trewin, H.; Gawthrop, F.; Wagstaff, C. Sesquiterpenoids lactones: Benefits to plants and people. Int. J. Mol. Sci. 2013, 14, 12780-12805. [CrossRef]

39. Erasto, P.; Grierson, D.S.; Afolayan, A.J. Bioactive sesquiterpene lactones from the leaves of Vernonia amygdalina. J. Ethnopharmacol. 2006, 106, 117-120. [CrossRef]

40. Nowak, G. Surowce roślinne stosowane w chorobach układu krążenia i serca. Herba Pol. 2009, 55, 100-120.

41. Libiszewska, K. Laktony jako związki biologicznie czynne. Biotechnol. Food Sci. 2011, 75, 45-53. [CrossRef]

42. Olesińska, K. Sesquiterpene lactones-Occurrence and biological properties. Agron. Sci. 2018, 73, 83-95. [CrossRef]

43. Merfort, I. Flavonoids from Arnica montana and Arnica chamissonis [Flavonoids aus Arnica montana und Arnica chamissonis]. Planta Med. 1985, 2, 136-138. [CrossRef]

44. Willuhn, G.; Junior, I.; Kresken, J. Sesquiterpene lactones from Arnica chamissonis. IV. Ivalin and other sesquiterpene lactones from flowers of the subspecies genuine [Aesquiterpenlactone aus Arnica chamissonis. Iv. Ivalin und andere sesquiterpenlactone aus den blutenkorbchen der subspecies genuina]. Planta Med. 1985, 5, 398-401.

45. Merfort, I.; Marcinek, C.; Eggert, A. Flavonoid distribution in Arnica subgenus chamissonis. Phytochemistry 1986, 25, $2901-2903$. [CrossRef]

46. Merfort, I.; Wendisch, D. Flavonoid glycosides from Arnica montana and Arnica chamissonis. Planta Med. 1987, 53, 434-437. [CrossRef] [PubMed]

47. Merfort, I. Acetylated and other flavonoid glycosides from Arnica chamissonis. Phytochemistry 1988, 27, 3281-3284. [CrossRef]

48. Willuhn, G.; Kresken, J.; Leven, W. Further helenanolides from the flowers of Arnica chamissonis subsp. foliosa [Weitere helenanolide aus den bluten von Arnica chamissonis subsp. Foliosa]. Planta Med. 1990, 56, 111-114. [CrossRef]

49. Merfort, I. Caffeoylquinic acids from flowers of Arnica montana and Arnica chamissonis. Phytochemistry 1992, 31, $2111-2113$. [CrossRef]

50. Roki, D.; Menković, N.; Šavikin-Fodulović, K.; Krivokuća-Dokić, D.; Ristić, M.; Grubišić, D. Flavonoids and essential oil in flower heads of introduced Arnica chamissonis. J. Herbs Spices Med. Plants 2001, 8, 19-27. [CrossRef]

51. Skubij, N.; Dzida, K. Influence of nitrogen dose and harvesting date on the yield and biological value of raw garden savory (Satureja hortensis L.) of Saturn cv. Acta Sci. Pol. Hortorum Cultus 2019, 18, 171-180. [CrossRef]

52. Sonmez, C.; Bayram, E. The influence of different water and nitrogen applications on some yield parameters and antioxidant activity in sage (Salvia officinalis L.). Turk. J. Field Crop. 2017, 22, 96-103. [CrossRef]

53. Shahhoseini, R.; Saeidi, K.; Babaahmadi, H.; Ebadi, M.T. Effect of fertilizers and superabsorbent hydrogel on the yield, essential oil content and composition of lemon verbena (Lippia citriodora Kunth.) cultivated in Iran. J. Essent. Oil Bear. Plants 2018, 21, 230-236. [CrossRef]

54. Heikal, A.A.M.; Helmy, S.S. Effect of nitrogen fertilization and ascorbic acid on growth, essential oil and chemical composition of rosemary plant. Zagazig J. Agric. Res. 2018, 45, 87-103. [CrossRef]

55. Foladvand, F.; Khoshkhabar, H.; Naghdi, N.; Hosseinabadi, M.; Bahamin, S.; Fathi, A. The effect of sowing date and nitrogen on yield, and essential oil of German chamomile. Sci. Agric. 2017, 19, 85-92. [CrossRef]

56. Król, B. Influence of nitrogen fertilization on the seed yield and the content and quality of fat in pot marigold (Calendula officinalis L.). Agron. Sci. 2017, 72, 85-98. [CrossRef]

57. Król, B. The effect of different nitrogen fertilization rates on yield and quality of marigold (Calendula officinalis L. "Tokaj") raw material. Acta Agrobot. 2011, 64, 29-34. [CrossRef]

58. Król, B. Yield and the chemical composition of flower heads of pot marigold (Calendula officinalis L. Cv. Orange king) depending on nitrogen fertilization. Acta Sci. Pol. Hortorum Cultus 2011, 10, 235-243.

59. Özyiğit, Y.; Uçar, E.; Tütüncü, B.; İndibi, İ.; Turgut, K. The effect of different nitrogen doses on yield and some yield components of Melissa officinalis subsp. L. altissima (Sibthr. et Smith) Arcang. Turk. J. Agric. Res. 2016, 3, 139-144. [CrossRef]

60. Abbaszadeh, B.; Safikhani, F.; Layeghhaghighi, M. Effects of irrigation interval and nitrogen amount on different clary sage (Salvia sclarea L.) characters in Karaj. J. Med. Plants Prod. 2017, 2, 139-144. [CrossRef]

61. Ninou, E.G.; Paschalidis, K.A.; Mylonas, I.G.; Vasilikiotis, C.; Mavromatis, A.G. The effect of genetic variation and nitrogen fertilization on productive characters of Greek oregano. Acta Agric. Scand. B Soil Plant Sci. 2017, 67, 372-379. [CrossRef]

62. Król, B.; Sęczyk, Ł.; Kołodziej, B.; Paszko, T. Biomass production, active substance content, and bioaccessibility of Greek oregano (Origanum vulgare ssp. hirtum (Link) Ietswaart) following the application of nitrogen. Ind. Crop. Prod. 2020, 148, 1-11. [CrossRef]

63. Chrysargyris, A.; Nikolaidou, E.; Stamatakis, A.; Tzortzakis, N. Vegetative, physiological, nutritional and antioxidant behavior of spearmint (Mentha spicata L.) in response to different nitrogen supply in hydroponics. J. Appl. Res. Med. Aromat. Plants 2017, 6, 52-61. [CrossRef] 
64. Tatar, Ö.; Bayram, E.; Gesheva, E.; Sönmez, Ç.; Atasoy, D.; Konakchiev, A.; Gevrek, M.N. Physiological and biochemical responses of Achillea millefolium group-related cultivar Proa to different nitrogen regimes. Biotechnol. Biotechnol. Equip. 2013, 27, $3649-3653$. [CrossRef]

65. Allahdadi, M.; Farzane, P. Influence of different levels of nitrogen fertilizer on some phytochemical characteristics of artichoke (Cynara scolymus L.) leaves. J. Med. Plants Stud. 2018, 6, 109-115.

66. Mijani, G.A.A.; Sharifabad, H.H.; Panahi, B. Determination of optimum N and P fertilization levels for dry flower yield and essential oil percentage in autumn-Grown German chamomile (Matricaria chamomilla) in Jiroft, Iran. Plant Ecophysiol. 2011, 3, 47-52.

67. Andrzejewska, J.; Woropaj-Janczak, M. German chamomile performance after stubble catch crops and response to nitrogen fertilization. Ind. Crop. Prod. 2014, 62, 350-358. [CrossRef]

68. Yang, M.S.; Tawaha, A.R.M.; Lee, K.D. Effects of ammonium concentration on the yield, mineral content and active terpene components of Chrysanthemum coronarium L. in a hydroponic system. Res. J. Agric. Biol. Sci. 2005, 1, 170-175.

69. Kim, D.K.; Lee, K.D. Effects of nitrogen application on growth and bioactive compounds of Chrysanthemum indicum L. (Gamgug). Korean J. Med. Crop Sci. 2009, 17, 363-368. [CrossRef]

70. Ghiasy-Oskoee, M.; Aghaalikhani, M.; Sefidkon, F.; Mokhtassi-Bidgoli, A.; Ayyari, M. Blessed thistle agronomic and phytochemical response to nitrogen and plant density. Ind. Crop. Prod. 2018, 122, 566-573. [CrossRef]

71. Wang, J.W.; Tan, R.X. Artemisinin production in Artemisia annua hairy root cultures with improved growth by altering the nitrogen source in the medium. Biotechnol. Lett. 2002, 24, 1153-1156. [CrossRef]

72. Sugár, E.; Fodor, N.; Sándor, R.; Bónis, P.; Vida, G.; Árendás, T. Spelt Wheat: An Alternative for Sustainable Plant Production at Low N-Levels. Sustainability 2019, 11, 6726. [CrossRef]

73. Dubey, R.K.; Dubey, P.K.; Chaurasia, R.; Rao, C.S.; Abhilash, P.C. Impact of Integrated Agronomic Practices on Soil Fertiity and Respiration on the Indo-Gangetic Plain of North India. Agronomy 2021, 11, 402. [CrossRef]

74. EMEA. Guideline on Good Agricultural and Collection Practice (GACP) for Starting Materials of Herbal Origin. London. 2006. Available online: http:/ / www.ema.europa.eu/docs/enGB/documentlibrary/Scientificguideline/2009/09/WC500003362.pdf (accessed on 22 July 2021).

75. Willuhn, G.; Kresken, J.; Wendisch, D. Sesquiterpenelactone aus Arnica chamissonis III: 4-0-acetyl-6-desoxychamissonolid und 6-0-propionyl-11,13-dihydrohelenalin. Planta Med. 1983, 47, 157-160. [CrossRef]

76. Sugier, D.; Sugier, P.; Kowalski, R.; Kołodziej, B.; Olesińska, K. Foliar boron fertilization as factor affecting the essential oil content and yield of oil components from flower heads of Arnica montana L. and Arnica chamissonis Less. cultivated for industry. Ind. Crop. Prod. 2017, 109, 587-597. [CrossRef]

77. Matławska, I. Farmakognozja; UM: Poznań, Poland, 2008; pp. 128-130.

78. Polish Pharmacopoeia VIII; The Republic of Poland, The Minister of Health: Warsaw, Poland, 2008.

79. Polish Pharmacopoeia VI; The Republic of Poland, The Minister of Health: Warsaw, Poland, 2002.

80. Abdi, H.; Williams, L. Principal components analysis. Wiley Interdiscip. Rev. Comput. Stat. 2010, 2, 439-459. [CrossRef]

81. Kovach, W.L. MVSP_A Multivariate Statistical Package for Windows Ver. 3.1; Kovach Computing Service: Pentraeth, UK, 1999.

82. Sugier, D.; Gawlik-Dziki, U. Wpływ nawożenia dolistnego na plonowanie i jakość surowca Arnica montana L. i Arnica chamissonis var. foliosa. Agron. Sci. 2009, 64, 129-139. [CrossRef]

83. Radanović, D.; Pljevljakušić, D.; Marković, T.; Ristić, M. Influence of fertilization model and PE mulch on yield and quality of arnica (A. montana) at dystric cambisol. Zemlj. Biljke 2007, 56, 85-95.

84. Giannoulis, K.D.; Kamvoukou, C.A.; Gougoulias, N.; Wogiatzi, E. Matricaria chamomilla L. (German chamomile) flower yield and essential oil affected by irrigation and nitrogen fertilization. Emir. J. Food Agric. 2020, 32, 328-335. [CrossRef]

85. Polara, N.D.; Gajipara, N.N.; Barad, A.V. Effect of nitrogen and phosphorus nutrition on growth, flowering, flower yield and chlorophyll content of different varieties of African marigold (Tagetes erecta L.). JAH 2015, 17, 44-47. [CrossRef]

86. Polish Pharmacopoeia XI; The Republic of Poland, The Minister of Health: Warsaw, Poland, 2017.

87. Ivanova, D.; Deneva, V.; Zheleva-Dimitrova, D.; Balabanova-Bozushk, V.; Nedeltcheva, D.; Gevrenova, R.; Antonov, L. Quantitative Characterization of Arnicae flos by RP-HPLC-UV and NIR Spectroscopy. Foods 2019, 8, 9. [CrossRef]

88. Özgüven, M.; Şener, B.; Orhan, I.; Şekeroğlu, N.; Kirpik, M.; Kartal, M.; Peşin, I.; Kaya, Z. Effect of varying nitrogen doses on yield, yield components and artemisinin content of Artemisia anuua L. Ind. Crop. Prod. 2008, 27, 60-64. [CrossRef]

89. Zheleva-Dimitrova, D.Z.; Balabanova, V.; Gevrenova, R.; Doichinova, I.; Vitkova, A. Chemometrics-based approach in analysis of Arnicae flos. Pharmacogn. Mag. 2015, 11, S538-S544. [CrossRef] [PubMed]

90. El-Leithy, A.S.; El-Hanafy, S.H.; Khattab, M.E.; Ahmed, S.S.; El-Ghafour, A.A. Effect of nitrogen fertilization rates, plant spacing and their interaction on essential oil percentage and total flavonoid content of summer savory (Satureja hortensis L.) plant. Egypt. J. Chem. 2017, 60, 805-816. [CrossRef]

91. Tshivhandekano, I.; Ngezimana, W.; Tshikalange, T.E.; Makunga, N.P.; Mudau, F.N. Nitrogen application influences quality, pharmacological activities and metabolite profiles of Athrixia phylicoides DC. (Bush tea) cultivated under greenhouse and field conditions. Acta Agric. Scand. B Soil Plant Sci. 2018, 68, 388-400. [CrossRef] 